\title{
A LITERATURA PORTUGUESA PERANTE AS REALIDADES CONTEXTUAIS LUSO-AFRO-BRASILEIRAS
}

\author{
CARLOS D'ALGE \\ (Professor titular da Universidade de Fortaleza e \\ professor adjunto da Universidade Federal do Ceará)
}

José de Alencar ao escrever o prefácio do romance Sonhos d'Ouro, em 23 de julho de 1872, pôs o problema da língua portuguesa falada no Brasil $\theta$ da literatura criada pelos brasileiros, respondendo, assim, a alguns críticos que do outro lado do Atlântico censuravam a obra do romancista, achando-a descuidada na forma e expressāo.

Invocando Alexandre Herculano que profetizara para o Brasil uma nacionalidade original, transfusāo de duas naturezas, a lusa e a americana, Alencar afirma que em Portugal decidira-se que näo poderia haver uma literatura brasileira. E mais, que a critica brasileira queria uma literatura realmente brasileira, mas o brasileirismo que Alencar entrevia era aquele que existia em Portugal antes da descoberta do Brasil. E conclui com certa ironia:

"Nosso português deve ser ainda mals cerrado, do que usam atualmente nossos irmãos de além-mar; e sobretudo cumpre erriçá-lo de hh e çç para dar-lhe o aspecto de uma mata virgem".

Efetivamente, Alencar reclamava da crítica menos culdados por causa dos neologismos de palavra e de frase, e mais dtenção à imitaçāo grosselra. Recusava-se, também, o romancista a escrever no Brasil "cousa que pareça vinda em conserva lá da outra banda, como a fruta que nos mandam em lata".

Para justlficar esse propósito estabelece uma curiosa comparação entre 
uma das mais populares frutas do país, a manga, e os livros realmente brasileiros:

"A manga, da primeira vez que a prova, acha-lhe o estrangeiro gosto de terebentina; depois de habituado, regala-se com o sabor delicioso. Assim acontece com os poucos livros realmente brasileiros: o paladar português sente neles um travo, mas se aqui vivem conosco. sob o mesmo clima, atraidos pelos costumes da familia e da pátria irmãs, logo ressoam docemente."

Pemata Alencar o seu prefácio com uma alusão a Jacob Grimm e a Max Müller, a respeito da apofonia, - ou da transformação mecânica das linguas pela modificaçāo dos órgãos da fala - interrogando:

"O povo que chupa o caju, a manga, o cambuci e a jabuticaba, pode falar uma lingua com igual pronuncia e o mesmo espírito do povo que sorve o figo, a pera, o damasco e a nêspera?" (1)

Vejamos as criticas a Alencar. Pinheiros Chagas dedicou um capitulo dos Novos Ensaios Criticos ao escritor brasileiro. Sob o título "Literatura Brasileira - José de Alencar: Iracema, lenda do Ceará", datado de 1867, ressalta as qualidades do "estilista prímoroso" e do "cronista símpático dos antigos povos brasileiros", ( $\left.{ }^{2}\right)$ mas aponta-lhe alguns senōes: a incorreçāo na linguagem e a preocupaçāo de fazer do "brasileiro" uma língua diversa do português. Entretanto reconhece que Iracema inaugurava uma literatura nacional.

Já o maranhense Henriques Leal também faz reparos à linguagem de Alencar. Em Lisboa, ao escrever sobre a literatura brasileira, critica o autor de $\mathbf{O}$ Guarani, provocando uma resposta de Alencar no Pós-Escrito da segunda ediçāo de Iracema. $H$. Leal revida os ataques num artigo intitulado "Ouestāo Filológica", motivando nova defesa de Alencar, que aproveitando o título de Questão Filológica responde mais uma vez ao seu colega maranhense.

No primeiro artigo, $\mathrm{H}$. Leal reconhece o talento de Alencar, mas tacha a sua linguagem e estilo de descuidados, desiguais e frouxos. Alencar defende-se no Pós-Escrito já referido. As razōes e considerações do romancista não possuem, afirma Gladstone Chaves de Melo, nenhum valor filológico. No entanto, constituem um documento interessantissimo no qual Alencar irá estabelecendo a idéla de um estilo brasileiro para a língua portuguesa.

No segundo artigo, incluido no livro "Lucubrações", o critico maranhense discorda de algumas praxes de Alencar, com respeito à sinalação das preposições, ao emprego do que $\mathrm{H}$. Leal chama de francesias e à regência de certos verbos. Alencar refuta, chamando H. Leal de "Idólatra do arcaismo". Realmente, alguns escritores portugueses, contemporâneos de Alencar, não haviam aprendido, suficientemente, a liçāo que lhes legara Garrett, nas Viagens na minha terra. Continuaram a insistir no purismo vernaculista. Nesse ponto. Alencar tinha razōes incontestáveis. O seu estilo era mais dinâmíco. 
adaptado às condiçōes da vida brasileira. Els af a grande novidade do romancista cearense, năo compreendida pelos críticos da época. Realmente, como assinala Josué Montello, numa fase em que Alencar pontificava reclamando a independencia da lingua portuguesa falada no Brasil, os escritores do $\mathrm{Ma}$ ranhāo impunham uma linguagem recolhida nas fontes clássicas. Reunidos em torno de Gonçalves Dias constituiam o chamado "Grupo Maranhense", para quem a pureza vernácula valia como ponto de honra. Reconheça-se, contudo, que nāo obstante a preocupaçāo da linguagem "escoimada e limpa, esse grupo rompera, nos debates do pensamento, sensibilidade, temas e forma, novos caminhos para a literatura brasileira". (3)

A propósito, vale a pena lembrar a afirmaçäo de Silvio Romero sobre o autor de l-Juca-Pirama:

"é o autor do que há de mais nacional e do que há de mais português na nossa literatura".

Alvaro Lins confirma essa afirmativa, justificando que Gonçalves Dlas foi o último poeta ou escritor a apresentar em estado de equilibrio o sentimento brasileiro ao lado da formação portuguesa.

A sinceridade dessa tendència, continua Alvaro Lins, (4) se tornara mais evidente em face da retificação feita por Lúcia Miguel Pereira, autora de uma biografia do poeta, ao caso das Sextilhas de Frei Antão. Lúcia Miguel Pereira contesta a hipótese de revide de Gonçalves Dias ao Conservatório, por motivo de linguagem. Em nenhum documento se refere o poeta às Sextilhas sob este caráter. A peça de Gonçalves Dias fora recusada por imoralidade. Não seria uma repetição do caso de Garrett, punido porque publicara o Retrato de Vênus?

A resposta de Alencar a Henriques Leal permaneceu inédita atė 1919 quando foi publicada na revista América Latina, dirigida por Tasso da Silveira a Andrade Murici, e que se editou no Rio de Janeiro entre 1919 e 1920.

Dos cinco capitulos da Questão Filológica que Alencar delxa incompleta, vale a pena transcrever a parte final. Ao citar Webster ("Desde que duas raças de estirpe comum separam-se, colocam-se em regiōes diferentes, a linguagem de cada um começa a divergir por vários modos") e Alfred Maury ("O gênio intelectual de um povo tem chegado a dar até à fraseologia, à sintaxe um caráter novo. E assim que os anglo-americanos, todos os dias alteram a pronúncia original de seu idioma de origem anglo-saxonla, e introcuções contractas (standard phrases) que recordam o gênio das línguas dos indigenas da América..."). Alencar aplica as teorias ao espanhol falado na América do Sul e ao português falado no Brasil. Teoriza Alencar:

"Passemos ao espanhol.

Não conheço a fundo esta língua, que apenas traduzo, e pois näo ouso emitir juízo próprio acerca da linguagem dos escritores argentinos, e chilenos que possuo, e tenho lido. 
Por intermédio de amigos procurei obter alguma obra publicada nas repüblicas vizinhas, e onde a questāo fosse tratada. Ainda não o consegui; mas sei pelo testemunho de pessoas autorizadas, que o estilo e a fraseologia da imprensa argentina difere tanto do espanhol europeu como o nosso português do lusitano.

Não há negar que os escritores da América, não achando na terra pátria vestigios e tradiçōes de uma literatura indigena, eram levados naturalmente a imitar os modelos da metrópole. Nesse empenho, por isso mesmo que sentiam o influxo irresistivel da natureza virgem que os separava do primitivo berço, exageravam-se em guardar as fórmulas consagradas.

Mas à medida que a revolução progride, esse artifício desaparece; e o escritor verdạdeiramente nacional acha na civilizaçāo de sua pátria, e na história já criada pelo povo, os elementos não só da idéia, como da linguagem que deve exprimir.

Os americanos do Norte desde muito já se emanciparam da tutela literária da Inglaterra. Chegará a vez da raça espanhola e brasileira."

E conclui numa maneira quase profética:

"Quando em vez de dez milhōes em que se conta um leitor por mil analfabetos, tivermos para nossos livros a circulação que dá Estados Unidos aos seus, nenhum escritor brasileiro se preocupará mais com a opiniāo que dele formarāo em Portugal. Ao contrário, serāo os escritores portugueses que se afeiçoarăo ao nosso estilo, para serem entendidos do povo brasileiro, e terem esse mercado em que se derramem." (5)

E com esse mesmo espirito que Alencar fala do "abraslleiramento" da língua portuguesa nas cartas que escreve a Joaquim Serra, reunidas depois nos cinco artigos com o título de $\mathbf{O}$ Nosso Cancioneiro, publicados originalmente no jornal O Globo, do Rio, em 1874. Na Questão Filológica, defendeu-se dos ataques, nāo justificou a criação de uma lingua brasileira, não houve. como acentua Gladstone Chaves de Melo "nenhuma insubordinação sistemática contra as normas da verdadeira língua literária". $\left.{ }^{[}\right]$

Antes de passar à crítica inserta no Nosso Cancioneiro, em que Alencar estabelece a diferença entre língua e estilo, convém referir, ainda que breve. as acusaçōes de que foi vitima na revista-panfleto Questōes do Dia, de que se publicaram quarenta números, reunidos em dois volumes: Questões do Dia - Observaçōes Politicas e Literárias, escritas por vários e coordenadas por Lúcio Quinto Clncinato, Rio, 1871. Cincinato era pseudônimo de José Feliciano de Castilho, "tipo do caturra, gramaticóide estreito, exsudando latim e erudiçăo clássica por todos os poros, arvorando-se em mestre do bom gosto. do estilo, e em paladino da vernaculidade". Entre os colaboradores desta- 
cava-se Franklin Távora, que sob o pseudônimo de Semprônio tentou reduzir. por clúme, os méritos literários de Alencar. Castilho analisou $\mathbf{O}$ Gaúcho e Til; Távora, o Gaúcho e Iracema. Acusaram Alencar de improprledades vocabulares e de cincadas em matéria de indianologia. Os censores foram, na verdade, além da medida, se realmente detectaram algumas impropriedades, também incorreram em equivocos.

Nas Cartas a Joaquim Serra, Alencar discorre sobre a poesia popular e acena para o conceito de estilo nacional. Muito antes do aparecimento da obra de Saussure, tem a Intuiçäo da diferença entre língua e estilo ou melhor entre a langue e parole do mestre de Genebra.

Uma das observaçōes de Alencar sobre o poema sertanejo Bol Espácio, então em voga no Ceará, merece destaque. Explica Alencar que Espácio significa o boi que tem a armação aberta e esgalhada. $O$ adjetivo formou-se seguindo o mesmo processo usado pelos cultores da língua. Assim, de Olimpo vem olimpio, de rosa, róseo, etc. Espácio, portanto, representaria a forma passiva de espaçado.

justifica Alencar que os povoadores do Brasil, desde a primeira ocupação, e após eles seus descendentes, estavam criando por todo o vasto território brasileiro um vocabulário novo, à proporção das suas necessidades. E afirma:

"Nós, os escritores nacionais, se quisermos ser entendidos de nosso povo, havemos de farlar-lhe em sua lingua, com os termos ou locuções que ele entende, e que lhe traduz os usos e as sentimentos.

Nāo é somente no vocabulário, mas também na sintaxe da lingua, que o nosso povo exerce o seu inauferivel direito de imprimir o cunho da sua individualidade, abrasileirando o instrumento das idélas".

Por outro lado, Portugal deveria ser admirado pelas tradições gloriosas do seu passado, nos esforços generosos do seu renascimento. Prezar a sua literatura e os seus costumes, porém nunca imitá-la servilmente. Impórtaria em anular a individualidade brasileira. Bastava de imitação. Mesmo a contragosto de muitos portugueses que criticavam a "embrionária e frágil literatura brasileira". Alencar faz uma exceção a Herculano; deveria, também, têla feito a Garrett, pois este notável escritor foi o primeiro a teorizar sobre a balbuciante literatura brasileira.

Remata Alencar as suas consideraçöes defendendo a existência de um estilo brasileiro:

"Se nós, os brasileiros, escrevéssemos livros no mesmo estilo e com o mesmo sabor dos melhores que nos envia Portugal, não passariamos de uns autores emprestados; renegariamos nossa pátria, e năo só ela, como a nossa natureza. que é o berço dessa pátria." (7) 
A quem atribuiu a José de Alencar intençōes de criar uma língua brasileira não examinou detidamente a sua obra critica. Alencar năo se refere a uma lingua brasileira mas sempre à lingua portuguesa falada com estilo brasileiro ou ao "abrasileiramento" da lingua portuguesa. Gladstone Chaves de Melo e Celso Cunha estudaram suficientemente o problema. Celso Cunha chama Alencar "um desses monstros de la naturaleza", considerando-o um profundo estudioso dos processos literários que se desenvolviam no Pais, e, sem sombra de dúvida, um lingũista, dentro das concepçōes cientificas da sua época. Foi Alencar quem, ao lado de Gonçalves Dias, apontou a necessidade de se estudar a influência dã língua tupi no português. Por ter sido, talvez, o tupi a impressāo mais profunda na parte fonológica da língua. 0 uso freqüente de palavras da língua tupi no falar cotidiano, para designar lugares, frutas, animais e árvores provocaria sensivel alteraçäo no vocalismo europeu.

Alencar conhecia - informa Celso Cunha - as idéias de Max Müller, cujas Liçōes sobre a Ciência da Linguagem saíram em dois volumes, entre 1862 \& 1864. "Em 1870 Alencar já havia meditado tanto nos seus ensinamentos, que sobre alguns deles tinha interpretaçōes pessoais." (B) Estas constam do Pós-Escrito, que aparece na segunda ediçăo de Iracema, e ao qual já nos referimos. Leiamos uma pequena parte destas interpretaçōes:

"O corpo de uma língua, a sua substância material, que se compõe de sons e vozes peculiares, esta só a pode modificar a soberania do povo, que nestes assuntos legisla diretamente pelo uso. Entretanto, mesmo nesta parte física e infalivel a influência dos bons escritores: eles talham e pulem o grosseiro dialeto do vulgo, como o escultor cinzela o rudo troço de mármore e dele extrai o fino lavor." $\left({ }^{9}\right)$

Dissemos que ao referir-se aos mestres portugueses que acreditaram no aparecimento de uma literatura brasileira. verdadeiramente autônoma, mencionara Alencar o nome de Alexandre Herculano. Não citara Almeida Garrett. Foi, no entanto, Garrett quem esboçou a primeira teoria sobre a literatura brasileira. Garrett, ele próprio, foi um notável inovador da língua e da literatura portuguesa. Mestre da estilística e da dialética fez a crítica dos clássicos que o haviam antecedido. No Bosquejo da História da Poesia e da Língua Portuguesa, de 1826, e, em 1828. no prefácio-manifesto da Lirica de Joäo Minimo analisou problemas contemporãneos relacionados com a evolução da lingua portuguesa. Dele é a afirmativa acerca da influência dos estrangeirismos: "Ouanto a estrangeiros, convém estudá-los, convém imitá-los no que é imitävel, nacionalizando-o; mas o que faz gala de imitar às tontas os estrangeiros e desprezar os seus, não é só tolo, é ignorante e estúpido". (10)

Herculano em carta dirigida a D. Pedro II - citada por José Osório de Oliveira no artigo A Literatura Brasileira em Portugal (II) — defende a autonomia para a nossa literatura: 
"Uma coisa de que também me parece carecer o Brasil 6 de nacionalizar a sua poesia, no que é possível nacionalizá-la. $O$ que acho nos pootas das Américas, salvas algumas honrosas exceçōes, devidas principalmente a Gonçalves Dlas, é a constante recordaçăo da Europa. Resulta isto das orlgens da sociedade brasileira, das suas relaçōes intimas com as socledades do mundo antigo. E o mesmo defeito dos nossos poetas moços em relaçäo à literatura francesa. Falta-lhes a autonomia. Os nossos bosques, o nosso céu, as nossas montanhas, os nossos rios em miniatura, os nossos hábitos, os nossos interesses, os nossos destinos, não são os mesmos do Brasil. Com o que o recente impérlo tem propriamente individual e autonómico no meio do seu europeismo, pode ter uma poesia individual e autonômica."

Mejo século depois Eça de Queirós, através de seu heterônimo Fradique Mendes, afirmava que um homem só deveria falar, com impecável segurança e pureza, a lingua da sua terra:

" $\mathrm{Na}$ língua verdadeiramente reside a nacionalidade; - e quem for possuindo com crescente perfelçäo os Idiomas da Europa vai gradualmente sofrendo uma desnacionalização. Não há jà para ele o especial e exclusivo encanto da fala materna com as suas influências afetivas, que o envolvem, o isolam de outras raças; $\theta$ o cosmopolitismo do verbo Irremediavelmente the dá o cosmopolitismo do caráter. Por isso o poliglota nunca é patriota. Com cada idioma alheio que assimlla, introduzem-se-lhe no organismo moral modos alheios de pensar, modos alhelos de sentir." [12]

Com graça e ironia Eça de Quelrós conclui - através do requintado Fradique - que o propósito de se pronunciar com perfeiçāo línguas estrangeiras constituia "uma lamentável sabujice para com o estrangeiro". Se Eça vivesse mais um pouco poderia encontrar em Saussure uma definição sobre a complexidade dos fatos de uma língua transformada num paradoxo: "Lingũista é aquele que nảo conhece nenhuma língua estrangeira e sabe mal a própria".

Voltemos a Garrett. No Bosquejo da HIstória da Poesia e da Língua Portuguesa fez a crítica dos nossos poetas arcádicos, dedicando algumas páglnas ao estudo das obras de Santa Rita Duräo, Tomaz Antonio Gonzaga, Cláudio Manoel da Costa e José Basilio da Gama. Ao autor da Marilia faz a seguinte recomendaçāo:

"Se houvesse por minha parte de the fazer alguma censura, só me queixaria, não do que faz, mas do que deixou de fazer. Explico-me quisera eu que em vez de nos debuxar no Brasil cenas da Arcádia, quadros intelramente europeus pintasse os seus 
painéis com as cores do país onde os situou. Oh! e quanto perdeu a poesia nesse fatal erro! se essa amável, se essa ingênua Marilia fosse, como a Virgínia de Saint-Pierre, sentar-se à sombra das palmeiras, e enquanto lhe revoavam em torno o cardeal soberbo com a púrpura dos reis, o sabiá terno e melodioso que saltasse pelos montes espessos a cotia fugaz como a lebre da Europa, ou grave passeasse pela orla da ribanceira o tatu esquarroso, - ela se entretivesse em tecer para o seu amigo e seu cantor uma grinalda não de rosas, não de jasmins, porém dos roxos martírios, das alvas flores dos vermelhos bagos do lustroso cafezeiro..." [13]

Crelo que foram estas as primeiras impressōes portuguesas sobre a nascente literatura brasileira. Reconhecendo Garrett o talento dos brasileiros desejava que estes aproveitassem as cores ou melhor a fisionomia do seu pais, deixassem de ser europeus e passassem a ser brasileiros. Por mais de uma vez, Garrett deixou transparecer esta simpatia crítica pelo Brasil esboçada em outros textos poéticos e em prosa sobre o nosso pais. Semelhante atitude tomaria Eça de Queirós - ainda sob a pele de Fradique Mendes, na conhecida carta endereçada a Eduardo Prado. Atendendo a solicitação deste escritor Eça disserta sobre o Brasil:

“O que eu queria... era um Brasil natural, espontâneo, genuino, um Brasil nacional, brasileiro e năo esse Brasil, que eu vi (visto obviamente pelo trinōmio Eça - Fradique - Eduardo Prado) feito com velhos pedaços da Europa..."

As considerações de Eça se estendem pelos costumes, instituiçōes políliticas, e pela doutorice que invadia o pais ("Do generoso e velho Brasil nada restou: nem sequer brasileiros, porque só havia doutores"). Explica Eça que o feitio especial da doutorice é desatender as realidades, tudo conceber a priori e querer organizar e reger o mundo pelas regras dos compêndios. E continua:

"São estes doutores brasileiros de nacionalidade, mas nāo de nacionalismo, que, cada dia, mais desnacionalizam o Brasil, The matam a originalidade nativa, com a teima doutoral de moralmente e materialmente o enfardelarem numa fatiota européla feita de francesismo, com remendos de vago inglesismo e de vago germanismo".

Verificada a doença, Eça concorre à metáfora do tapete. Arrancá-lo eis a soluçāo. A chance que poderá trazer salvação ao nosso pais:

"... no dia ditoso em que o Brasil, por um esforço heróico, se decidir a ser brasileiro, a ser do novo mundo - haverá no mundo uma grande naçăo. Os homens têm inteligência; as mulheres têm beleza - e ambos a mais bela, a melhor das qualidades: a bondade. Ora uma nação que tem a bondade, a inteli- 
gência, a beleza (e café nessas proporções sublimes) - pode contar com um soberdo futuro histórico, desde que se convença que mais vale ser um lavrador original, do que um doutor mal traduzido do francês". (14)

Garrett e Eça de Queirós possuem a mesma visāo crítica sobre os problemas culturais braslleiros. Eles próprios foram os grandes reinventores da lingua portuguesa. Transformaram, atualizaram e modernizaram o idioma. Basta ler as Vlagens na minha terra, de Garrett, para identificar a mudança. Ou os romances de Eça, do Padre Amaro à Relíquia. Garrett fez retornar a língua às suas origens rurals $\theta$ populares, trazendo para a sua narrativa a linguagem dos camponeses e dos pescadores portugueses. Eça manipulou satanicamente o adjetivo, e fez do advérbio, através de um processo de intensificaçāo,o seu escalpelo. Garrett utilizou a sintaxe popular, como bem acentua um dos seus estudiosos, Augusto da Costa Dias, para dissolver a sintaxe erudita, e resolver a oposiçāo entre a linguagem falada e a linguagem escrita. (15)

Num dos textos de Garrett, insuficientemente estudado, o romance que nāo chegou a acabar, Helena, aparece a figura de um empregado preto, mordomo de uma familia rica no interior da Bahia, chamado curiosamente pelo romancista de Spiridlão Casslano di Mello i Mattōss, grafado ao estilo do falar brasileiro. O nome traz à evocação dois fatos, um ligado à vida acadêmica de Garrett em Coimbra, e o outro episódio da Independência do Brasil. Garrett teve como companheiros, entre outros, três colegas naturais da Bahia e que estavam a estudar em Portugal. Chamavam-se Francisco Gomes Brandāo Montezuma, Rodrigo de Sousa da Silva Pontes Malheiro e Casslano Esperidião de Malo e Matos. (19) Foi este último quem inspirou a Garrett a cria çāo literária de Spiridiāo. A curiosidade do texto garrettiano, escrito em 1853, entre as suas implicações sociais e psicológicas, a causa do abolicionismo e a posiçāo ideológica do autor, registre-se agora, para ilustraçāo do tema, a que resulta dos diálogos em que intervém o criado Spiridlão. Garrett fez questão de reproduzir a linguagem coloquial do negro balano, certamente influenciado pelos baianos que estudavam em Coimbra.

Alguns exemplos:

"Não chama Cazuza, não. Chama Spiridião Casslano de Mello i Matōss, pa servi Sió Generá....".

"Spiridlão Cassiano, mordomo do Sió Visconde, velo por orde d'êri, fazê discurpa a Sua Esserença de não podê vi, por está assl mesmo".

“Doente meu siô, não stá. Sinhá é que stá doente. Siô Visconde com muito cuidado. Na carta diz, sí fá favô di lé".

Ressalvando-se a linguagem atribuida aos negros vindos de Angola, à época da colonização, pois Gil Vicente já os introduz em seus Autos, e conhecida por Garrett, não está longe de se supor que os três baianos, seus contemporaneos da Universidade, Ihe tenham sugerido dar aos diálogos de Helena maior realismo. 
Com referēncia ao episódio da Independência assinalemos que Garrett sempre se manifestara favoravelmente à libertaçāo do Brasil e por mais de uma vez saudou a nossa Independência com entusiasmo progressista. $O$ seu amigo baiano Francisco Gomes Brandāo que juntou ao seu nome o do rei asteca Montezuma, adotaria à proclamaçāo da Independência o nome de Francisco Gê Acaiaba de Montezuma. E que os patriotas brasileiros agressivamente nacionalistas passaram a repudiar os nomes portugueses, adotando sobrenomes como Jaguaribe, Japiaçu, Piragibe, Pitanga, Sucupira, Tupinambá, Cotegipe e Pirajá. No entanto, se os políticos se revoltaram contra os nomes portugueses, não adotaram o mesmo procedimento quanto à lingua que herdaram dos portugueses que aqui aportaram nos quinhentos.

Não vingou a idéia de uma língua nacional, própria, desvinculada da portuguesa. Nem como a que desejavam alguns dos nossos modernistas de 1922, que assumem atitudes criticas e renovadoras, como o fizeram Garrett, Eça de Queirós e os modernistas portugueses de 1915. A língua própria que se queria para o Brasil resumia-se nas teorias de José de Alencar. Não se tratava propriamente de se criar uma lingua mas sim um estilo brasileiro. Ou melhor. reagir contra o purismo e a gramatiquice retrógrada, contrária a inovações.

A lingua do Brasil, quer na sua forma culta, quer na popular, é essencialmente a lingua portuguesa, demonstrou-o Silvio Elia ao estudar a difusão das linguas européias e a formação das variedades ultramarinas. Admite aquele lingüista que a influência afro-índia limitou-se a algumas alterações positivas de caráter geral e outras negativas, no sentido de permitir a constituição de falares de emergência, crioulos ou semi-crioulos. Por outro lado. a relativa unidade do português falado no Brasil deve-se ao processo de colonização, segundo o qual uma língua comum já constituída se foi impondo de cima para baixo aos núcleos populacionais do litoral e depois dirigilu-se para 0 interior. ${ }^{(1 T)}$

Os modernistas de 1922 pensaram numa lingua nacional, isto é, numa lingua que valorizasse o substrato indigena e refutasse o vernaculismo dos retóricos brasileiros encastelados nas academias, tribunais e minlstérios. Queriam um discurso vivo, autêntico, coloquial - nāo o quis assim Garrett? Não o exereceu assim Eça de Queirós? - onde houvesse, como em Mário de Andrade. a reiteração do nosso tão coloquial pra, pro. Ou como pedia Oswald de Andrade no manifesto Falaçăo:

"A língua sem arcaismos. Sem erudição. Natural e neológica.

A contribuição milionária de todos os erros".

A Gramatiquinha da Fala Brasileira, de Mário de Andrade, nāo passou de uma boa brincadeira, em defesa do ideário da Semana de Arte Moderna. Em carta a Sousa da Silveira, publicada somente em 1964, na Revista do Livro, Mário afirma:

"Este livro, do qual nunca escrevl nenhuma página, eu nunca jamais tive intenção de escrever. E certo que tomei muita 
nota, fiz muita ficha, a respeito da língua, e de processos que me pareciam mais nacionais de traduzir o pensamento em linguagem, mas é só. Eu anunciava o livro, apenas para indicar a todos que o que estava tentando não era tentado assim ao até das recordaçōes, mas uma coisa séria, sistemática, e bem pensada. Nem isso valeu aliás. Até amigos íntimos imaglnavam que eu estava orgulhosissimamente querendo... inventar a língua do Brasil". (18)

Os modernistas brasilelros repensaram a nossa literatura em termos de crítica a afirmação. Pensar no Brasil - como assinala Afrânlo Coutinho interpretá-lo, procurar integrar a cultura na realidade brasileira, enfatizar os valores da nossa civilização e as qualidades regionais de nossa cultura, dar relevo às nossas coisas, pôr em destaque as nossas características raciais. culturais e sociais, reivindicar os direitos de uma fala que aqui se especializou no contato da rugosa realidade, eis os pontos básicos de um programa nacionalista brasileiro. (10)

Dessa tomada de consciência brasileira - que se assemelha em muitos traços - à posição assumida pelos modernistas portugueses de 1915/17. com os manifestos Anti-Dantas e Ultimatum, resultou uma conseqüência útil para a lingua portuguesa falada no Brasil. Defendeu-se ou melhor voltou-se a defender, aquele estilo braslleiro por que já lutara José de Alencar. Recusou-se a aceitação dos modelos vigentes, como Rui Barbosa e Coelho Neto, que utilizavam uma linguagem arcaizante e lusitanizante. Peregrino Júnior registra essa conseqüência:

"Libertou os escritores brasileiros de uma imemorial e voluntária subordinaçăo aos Cânones clássicos de Portugal, permitindo-lhes adotar uma linguagem mais livre, mais solta, mais natural, de inspiraçăo regional e popular, o que representou sem dúvida um enriquecimento e uma libertaçăo para a nossa lingua literária, tornando realidade aquilo que os românticos, Alencar à frente, tentaram fazer em pura perda". (20)

Assinale-se que a tentativa de libertaçăo iniclada por Alencar teve em Euclides da Cunha o seu continuador e em Araripe Júnior, Silvio Romero o José Veríssimo os seus criticos. Araripe Júnior chegou a criar a teoria da obnubilaçăo para explicar o fenômeno da diferenciaçăo.

A lição dos modernistas de 22 fol aproveltada pelos escritores contem. porâneos. Já descobrira Rubem Braga que os pós-modernistas haviam levado vantagem. Ao recusar a linguagem lusitanizante dos acadêmicos brasilelros muitos modernistas incidiram no erro de escrever sem dignidade. Os pós-modernistas aproveitaram bem a lição. Os modernistas fizeram mal a si mes. mos porque se preocuparam demasiadamente com a lingua prejudicando 0 próprio trabalho. Os pós-modernistas, segundo Rubem Braga, não tinham mais porque se preocupar com casticismos nem com barbarismos. Ou melhor, 
foram escrevendo na língua que thes parecia mais cômoda, mais fácil de escrever e ser entendida. (21)

Contam-se às centenas as ediçōes de livros braslleiros em Portugal. A par da intensa atividade editorial, destaquem-se os cursos de literatura brasileira e as atividades dos Instituto de Estudos Brasileiros do Porto, Coimbra e Lisboa.

Teófilo Braga, José Osório de Oliveira, Alberto de Serpa, Vitorino Nemésio, Arnaldo Saraiva, Fernando Cristóvão, O'scar Lopes, entre outros, dedica. ram páginas, antologias e estudos à literatura escrita no Brasil. Teófilo Braga considerou o lirismo brasileiro como superior em veemência sentimental e em novidades de forma ao lirismo português, fazendo incluir no seu Parnaso Português Moderno, poetas brasileiros. José Osório de Oliveira escreveu uma Breve História da Literatura Brasileira, e publicou antologias de contos e poesias brasileiras, além de desenvolver notável atividade como ensaista e critico de obras contemporâneas. Foi ele quem divulgou em Portugal a obra de Cornélio Pena, magistral ficcionista mineiro e nāo suficientemente conhecido pelas atuais geraçōes.

O interesse de José Osório de Oliveira pela literatura brasileira vai ao ponto de criticar a obra de Aubrey Bell sobre a literatura portuguesa, pela insuficiência de referências a escritores brasileiros e pela ausência de notas do tradutor - que foi Agostinho de Campos - sobre os nossos escritores. Vitorino Nemésio escreveu numerosos ensaios e crōnicas sobre temas brasileiros. Arnaldo Saraiva estudou a poesia de Carlos Drummond de Andrade: Fernando Cristóvão analisou a obra de Graciliano Ramos; e Oscar Lopes fez a critica de Guimarães Rosa, Lygia Fagundes Telles e João Cabral de Melo Neto.

Convém referir, como contribuiçāo ao conhecimento da literatura brasileira, os cursos regulares e os de férias das Faculdades de Letras de Coimbra e Lisboa, onde sempre se incluem cursos de literatura brasileira, ministrados por professores brasileiros. Lá estiveram, entre outros, Guilhermino César, Temistocles Linhares, Leodegário A. de Azevedo Filho, Gladstone Chaves de Melo. Celso Cunha, e Albino de Bem Veiga.

Num desses cursos, em Coimbra, nas férias de 1935 Cecilia Meireles falou sobre os novos poetas brasileiros na conferencia a que deu o título de Noticia da Poesia Brasileira.

A inesquecivel autora de Mar Absoluto leu poemas de Manoel Bandeira. Gilka Machado, Rosalina Coelho Lisboa, Ronald de Carvalho, Ribeiro Couto. Mário de Andrade, Guilherme de Almeida, Oswald de Andrade. Felipe d'Oliveira, Augusto Meyer, Jorge de Lima, Tasso da Silveira, Carlos Drummond de Andrade, Murllo Mendes, Murilo Araújo, Francisco Karam e Raul Bopp.

A literatura brasileira produzida a partir da renovação modernista terá alguma influência em alguns escritores portugueses. Erico Veríssimo, Jorge 
Amado, Graclliano Ramos, José Lins do Rego, Amando Fontes, Rachel de Queirós, Cecilia Meireles, Jorge de Lima, Guimarães Rosa, Joāo Cabral de Melo Neto, serão lidos intensamente em Portugal. Durante os anos mais rigorosos em que a censura portuguesa retirou llvros do mercado, de autores portugueses e estrangeiros, cresceu o Interesse público pelo chamado romance nordestino brasileiro. Especialmente pelos livros de Jorge Amado e Graciliano Ramos entāo proibidos naquele país. Fernando Mendonça estudou muito bem o problema da influêncla daqueles ficcionistas brasileiros no neorealismo portugués, examinando, detidamente, alguns romances de Alves Redol, Soeiro Pereira Gomes e Carlos de Oliveira, apontando algumas aproximaçōes entre os estilos de Graclliano Ramos e Carlos de Oliveira, entre Jorge Amado e Alves Redol e entre Soeiro Pereira Gomes, dos Estelros com os Capitães de Arela, de Jorge Amado. Todavia, mostra como são diferentes as atitudes ideológicas do "movimento do Recife" e do neo-realismo português. O que há propriamente é um testemunho e não uma influência. Ou melhor, as atitudes perante o conflito sócio-econõmico de nordestinos brasileiros e de portugueses sāo muito diferentes.

"Os neo-realistas deixaram-se empolgar pela oportunidade e pela riqueza dos temas ou das situações gerados pelos romances do nordeste brasileiro. Com eles se exercitaram na coragem de escolher caminhos que tanto lhes convinha trilhar. E isso o fizeram. criando as referidas semelhanças, que são afinal idênticas oportunidades de comoção poética. A miséria, a fome, a injustiça social, a infância abandonada, o furto, a vagabundagem, e o desprezo olimpico dos solidamente estabelecidos na vida por tudo isso é.igual em todas as partes da terra". (22)

Dos escritores neo-realistas o mais acusado de sofrer influências brasileiras foi Alves Redol. Pelo fato, informa Fernando Mendonça, de que na época conhecia-se mais em Portugal a obra de Jorge Amado. Gaspar Simóes chegou a acusar Redol de "escrever brasileiro". Gaibéus para Gaspar Simōes seria influenciado por Mar Morto.

O "escrever brasileiro" acusava a recusa em aceitar um romance escrito em novo estilo. Um romance depoimento, um romance testemunho, que fugia totalmente ao modelo existente. Dai a crítica.

Ora o "escrever braslleiro" seria também um testemunho de que, pela primeira vez, apareciam em Portugal textos com algumas marcas brasileiras. Sejam estas literárias ou lingüisticas. O fato näo pode passar em claro. A influência brasileira tende a crescer em Portugal, pois são os brasileiros numericamente superiores a quatro quintos da comunidade de língua portuguesa. Os traços dessa influêncla podem ser desde já detectados no jornalismo, na música, nas comunicaçōes, de uma maneira geral, e na própria literatura.

O caso de Carlos Drummond de Andrade é singular. Integrando a segun- 
da fase da poesia modernista - Alguma Poesia é de 1930 - Drummond encontraria estabilizada a revoluçāo desencadeada pela semana de 22.

Em muitos dos poemas de Alguma Poesia, Drummond foge da norma lingüistica moderna e culta de Portugal. Já em Poesias, de 1942, faz inúmeras correçōes de versos anteriores. Arnaldo Saraiva anotou criteriosamente essas ocorrências. Diz-nos que Drummond ( ${ }^{23}$ ) nunca abordara diretamente o problema, "salvo em duas passagens breves de um artigo". Numa delas afirmava que os brasileiros possuiam uma "língua semi morta"; e, no outro, ponderava "chegamos, è fato, à compreensāo de uma dolorosa necessidade, a necessidade de sermos brasileiros dentro do Brasil, na língua como no sangue. e na literatura como na língua". Explica Drummond que a lingua só se poderia renovar "à custa de indisfarçáveis prodígios de adaptaçāo e vivificação" e que isso não se faria com um manifesto ou conferência.

Algumas das ocorrências lingũisticas verificadas por Arnaldo Saraiva ilustram o problema.

De Alguma Poesia, de 1930:

"No meio do caminho tinha uma pedra".

"Hoje tem festa no brejo".

"Diz-que tem modernistas apaixonados pelo negro. Tem?".

"Minha māe ficava sentada cosendo".

"Me parece".

"O poeta chega na estação".

"A coxa morena / que ninguém repara".

"Mas quando la te pegar e te fazer minha escrava voce fez o sinal da Cruz".

Em Poesias, de 1942, Drummond fez as seguintes correçōes: "Tem dias" para "Há dias".

"A coxa morena / que ninguém repara" para "A coxa mo rena / em que ninguém repara".

"Está a sonhar? Olha que a sopa esfria" para "Está sonhando? Olhe que a sopa esfria".

"Ele veio na rede" para "Ele veio para a rede".

"Os homens não melhoraram / e se matam como percevejos" para "Os homens nāo melhoraram / e matam-se como percevejos".

Ficam aí os exemplos. Vale a pena transcrever, para llustraçāo, a carta de Mário de Andrade dirigida ao poeta e incluida nas Confissōes de Minas:

"Foi uma ignominia a substituiçāo do na estação por à estaçăo só porque em Portugal palzinho desimportante pra nós diz assim. Repare que eu digo que Portugal diz assim e năo escreve só. Em Portugal tem uma gente corajosa que em vez de ir 
assentar como é que dizia na Roma Latina e moderna, fez uma gramática pelo que se falava em Portugal mesmo. Mas no Brasil o sr. Carlos Drummond de Andrade diz "cheguel em casa", "fui à farmácia", "vou no cinema" e quando escreve veste um fraque debruado de galego, telefona para Lisboa e pergunta pro ilustre Figueiredo: - Como é que se está dizendo agora no Chiado: é "chega na estação" ou "chega à estação?". E escreve o que o sr. Figueiredo manda. E assim o Brasil progride com constituiçāo anglo-estadunidense. língua franco-lusa e outras alavancas fecundas e legítimas. Veja bem, Drummond, eu nāo digo pra voce que se meta na aventura que me metl de estilizar o brasileiro vulgar. Mas refugir de certas modalidades nossas e perfeita. mente humanas (...) é preconceito muito pouco viril".

A presença brasileira em Portugal, acrescente-se a participaçāo africana dos povos de expressão portuguesa. Após a descolonização, tornados Independentes e livres da opressão colonialista, poderão os novos países realizar um programa literário pertinente com as suas raizes culturais e étnicas. Alguns escritores africanos já sāo muito lidos em Portugal, como os cabo. verdianos Manuel Lopes, Baltazar Lopes, e o continental Manuel Ferreira, com o seu Hora di Bai, reflexo das impressões culturais de Cabo Verde, e Castro Soromenho, com os notáveis romances Viragem e Terra Morta: os angolanos Oscar Ribas, Mário Antonio, Gerardo Bessa Victor, Mário de Andrade - que publicou em 1958 a Antologia da Poesia Negra de Expressão Portuguesa -. Agostinho Neto, Antonio Jaclnto, Viriato da Cruz, Alexandre Däskalos, José Luandino Vieira, Antonio Cardoso; os moçambicanos Kalungano, Noêmio de Sousa, Valenta Malangatana, José Craveirinha, Vigilio Lemos e Rul de Noronha; os sāo-tomenses Francisco José Tenreiro, Tomás Medeiros e Alda do Espirito Santo; os caboverdianos Baltasar Lopes, Jorge Barbosa, Eugênio Tavares, Onésimo Silveira e Gabriel Mariano.

A negritude e os traços culturais daqueles paises poderăo oferecer novas perspectivas aos escritores portugueses que irão aparecer. Entre o angolano Luandino Vieira e alguns dos nossos escritores poderiam ser estudadas possiveis afinidades, como as divergências em relação ao português-padrāo falado e escrito em Portugal. Assim, em Luanda, o livro premiado de Luandino Vieira, publicado em edições clandestinas antes do 25 de abril e que motivou o fechamento da Sociedade Portuguesa de Escritores em 1964, pela concessāo do prêmio, ocorre, como no Brasil, o uso do Ter como predicado de existência em oposição ao Haver, usado em Portugal. O emprego das preposiçōes em Luandino Vieira também sugere semelhanças com a maneira brasileira de escrever. A economia de preposiçōes aproxima, também, a linguagem de Luandino à do nosso Guimarāes Rosa. Assim, as indicaçōes de causa, estudadas por José Martins Garcia, prescindem da preposição em expressōes que a explicitam (por causa e nāo por causa de), chegando mesmo à supressão da própria expressāo, como em 'Kam'tuta sofria, mas nāo eram as coisas que lhe diziam, nāo". (2-1) 
A novidade nesse tipo de linguagem não está na presença de vocábulos de origem africana ou quimbundo mas na realizą̧ão de um discurso que o torna diferente do falado e escrito na metrópole. Independentes Angola, Moçambique, Guiné, Cabo Verde, São Tomé e Principe, associados ao Brasil, constituirão uma comunidade de cerca de 120 milhões de habitantes a que se juntarão os dez milhōes de portugueses, integrando um sistema lingüistico que absorverá as pecullaridades de cada povo.

A língua portuguesa, tomada como sistema ou código, é a mesma naqueles paises. Segundo Darmesteter, citado por Leodegário A. de Azevedo Filho, a lingua pode mudar o seu léxico e a sua sintaxe. Mas se não mudarem as formas gramaticais, permanece a mesma. [ ${ }^{(2)}$ ] Entre o português falado no Brasil e o português falado em Portugal não há divergência de formas gramaticais. Nos paises africanos de expressão portuguesa, devem ser resguardados os dialetos de cada um dos povos nativos. Os caboverdianos e os são-tomenses falam o dialeto crioulo, oriundo do português arcalco de mistura com as línguas nativas. Em Angola 70 por cento da população negra fala uma destas quatro linguas: umbundu, quimbundu, quicongo $\theta$ chokwe-lunda. Na Guiné fala-se o balanta, fula e mangaço. Em Moçambique, o makua-lomwe, tonga e shona.

O português como língua segunda é falado nesses paises por cerca de 70 por cento da população nāo-lusófona, ou seja, por mais de 8.5 milhōes de habitantes. A necessidade de escolha de uma lingua franca estrangeira, no caso, a portuguesa, decorre do multilingüismo da Africa, e das exigências de contacto cultural e técnico com o exterior. (26)

$E$ bastante expressivo, pois, $O$ fato de que o português continuará a ser a língua de comunicação dos povos angolanos, moçambicanos, são-tomenses, guinéus, caboverdianos, em suas manifestaçōes culturais, cientificas, técnicas ou politicas. Não é de todo inconveniente recordar que a alfabetização dos guinéus se processou por meio de cartilhas em português e que foi através dessa lingua que líderes nativos, como Amilcar Cabral e Samora Machel conduziram a Guiné e Moçambique à independência.

O fato mais importante no português falado no Brasil é o enriquecimento morfológlco. Assim, o nosso vocabulário foi expressivamente aumentado com a uttlização dos dialetos africanos $\theta$ das línguas indígenas. $O$ português, língua com formas de expressāo já muito apuradas no século XVI, nāo se deixou absorver em escala grande pelo Banto - registra Luis Silveira. (27) Guardou das línguas africanas algumas palavras, das quais número elevado nada tem com 0 português do Brasil e entrou no português da metrópole por intermédio do árabe ou pelo contacto direto, in loco, com os negros da Africa, disso resultando o enriquecimento da língua. Por outro lado, numerosos arcaismos foram rejuvenecidos e se mantêm revitalizados no falar do povo e na lingua literária, especialmente no nordestino brasileiro. Diversidade na unidade. Diversidade fonológica, morfológica, sintática, fraseológica e semântica. Todo esse acervo pesará, fatalmente, e justificará a profecia de 
Alencar, citada anteriormente, na qual previa o autor de lracema que os escritores portugueses se afeiçoariam ao estilo brasileiro, para serem entendidos pelo nosso público e "terem esse mercado em que se derramem".

A unidade da língua portuguesa - citemos Celso Cunha - só poderá ser obra de cultura comum. Não se poderá contar apenas com os clássicos porque quem governa a língua são os escritores e pensadores do momento. O livro, a revista e o jornal são agentes poderosos, já que é a língua escrita que consubstancia a norma do falar geral. A unidade em lingüistica nāo é incompativel com a variedade, antes a pressupōe. (28) A língua portuguesa na atualidade representa um vasto territórlo plurirracional e plurilingüistico. Esse territórlo abrange quatro continentes e sete povos independentes, além de Macau, Goa e outros enclaves lingüistlcos. São quase 130 milhōes de pessoas a falar a lingua portuguesa, resguardados os traços essenciais que ainda permitem a compreensão entre os falantes cultos, diferenciada em atendimento a impllcações de ordem geográfica, social $\theta$ até individual. Brasileiros, angolanos, moçambicanos, guinéus, caboverdianos, integram as variedades nacionais do português atual.

Em relaçāo à Africa de língua portuguesa, pelas implicaçōes históricas e políticas estamos mais ligados a Angola. Independente o Brasil, Angola que Já estava mals vinculada a este pais, preferiu estreitar conosco relaçōes mais Intensas e fecundas. Durante um importante período da nossa história tivemos relações com Angola, sendo interrompidas em 1830, por força dos interesses portugueses e a açáo do coloniallsmo entāo imperante. Nesse periodo, houve uma troca de experiências muito benéficas para Angola e Brasil. Segundo o estudo realizado por Manuel dos Anjos da Silva Rebelo que investigou as relações entre Angola e o Brasil nos anos de 1808 a 1830, (20) foi um brasileiro o primeiro médico nomeado para Luanda, que além de ali ir exercer a medicina levava a incumbência de fundar uma escola médica, a primeira do continente africano ao sul do Saara. Médicos angolanos, por sua vez, viriam a ser professores da Academia Médico-Cirúrgica do Rio de Janeiro. Estudantes de Luanda e Benguela vieram ao Rlo para estudar Medicina. Muitos militares que serviriam em Angola graduaram-se na Academia Militar do Rio de Janeiro, criada pelo príncipe-regente. O Museu de História Natural do Rio de Janeiro foi enriquecido com a fauna vinda de Angola. Assim D. João VI pedia ao Governador de Angola que the enviasse em cada navio que partisse para o Brasll "um viveiro de pássaros esquisitos". As primeiras zebras chegadas ao Rio de Janeiro, oriundas de Benguela, foram remetidas ao Brasil para divertimento dos príncipes D. Pedro e D. Miguel. Havia, portanto, um intercâmbio direto e permanente entre os portos brasileiros a os portos angolanos.

Ao interromper com o Brasil as suas relaçōes culturals, comercials e econômicas, Angola atravessou uma grande crise. Portugal apressou-se a restaurar o comércio e a ocupar os portos ao norte do Rio Lifune, para evitar a concorrência estrangeira. A partir daí, acabados os vínculos diretos com 
- Brasll, somente se pôde intercambiar com aquele rico pais por intermédio de Lisboa.

A poesia e a ficçāo de Angola, principalmente, têm obtido maior divulgação entre o públlco luso-brasileiro. Anterlormente à independência daquele pais já se haviam editado em Portugal e no Brasil obras de Castro Soromenho e algumas antologias poéticas. Roger Bastide, que estudou temas luso-afro-brasileiros, reconhece em Castro Soromenho um dos mais fiéis escritores à Africa. Efetivamente, Castro Soromenho, durante vinte anos, coligiu no interior de Angola, o material necessário à realização dos romances Nhári, Noite de Angústia, Terra Morta, Viragem. E nestes dois últimos romances que se delineiam os problemas que conduzirão aqueles povos à luta anti-colonialista e posteriormente à independência.

Cabe assinalar a participação nos princípios da década de 50 da Casa dos Estudantes do Império, em Lisboa, e das repüblicas estudantís de am. biência africana, em Coimbra, na divulgação dos escritores africanos de língua portuguesa e na luta contra a censura. Nesse periodo é que se desenvolve intensa atividade dos então estudantes Mário de Andrade, Agostinho Neto, Francisco José Tenreiro e Amilcar Cabral.

O romance nordestino brasileiro também influenciará os jovens escritores africanos. Artigo recente, publicado na revista Afriscope, editada em Lagos, Nigéria, de autoria de Isa Maria Drummond Simōes e Willfred Feuser, sob o título Some Aspects of African Literature in Portuguese, refere-se à influência do romance Jubiabá, de Jorge Amado, num poema do angolano Mário Antonio.

A viragem histórica propiciada pelo 25 de abril modificou o quadro literário das entāo chamadas Provincias Ultramarinas. Ainda é cedo para avaliar a que caminhos chegará a literatura de cada pais libertado. O certo é que, se tomarmos Angola como exemplo, verificaremos que ao longo de 15 anos os "poetas e intelectuais subordinaram as suas obras a um tema constante: a revolta, a revolta perante uma situaçāo aviltante para o povo angolano". (ïu)

Esperemos que, agora, libertos, possam os povos africanos, cuja segunda língua é o português, prosseguir como no poema do angolano David Mestre:

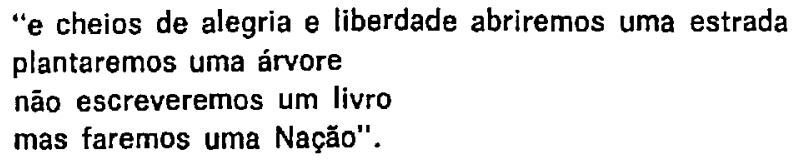

A independência de Angola enseja, agora, novas mudanças e perspectivas que serão benéficas para o Brasil e Luanda. Estabilizado o governo angolano é necessário que se incremente esse intercãmbio e se inicie uma nova cooperação técnica, cientifica e cultural. Os brasileiros estão muito presos à cultura angolana pelas suas raizes. Câmara Cascudo que viajou à entāo chamada Africa Portuguesa investigou a alimentaçāo africana, de onde provêm muitos elementos básicos da cozinha brasileira. Do seu livro Made in Africa 
(31) há um delicioso capítulo sobre Luanda. Luanda que está presente nos maracatus do Recife, nos poemas de Ascenso Ferreira e Jaime Griz, na música de Guerra Peixe. Evoca Cascudo os negros de Golana, cantando enquanto descarregavam abacaxis, diante do Hotel Lusitano, em 1924:

"Vou-me embora pra Luanda,

A vida lá é mió...

Escalé de doze remo,

Meia lua e meio só..."

Em Salvador, onde não há maracatu, diz Cascudo que ouviu de Odorico Tavares uma toada cantada pelos pescadores do xaréu no Chega-Negro:

"Só, só

Eu venho sól

Quando venho de Aruanda,

Eu venho só!

Eu deixei pal.

Eu lá deixeí vó!

Só, só

Eu venho sól

Quando venho de Aruanda,

Eu venho sól"

Informa Cascudo que os brasileiros nascidos entre Sergipe e o Ceará sentirão o ambiente nordestino com maior acuidade quando conhecerem Luanda. Reencontrarão, a cada passo, os velhos negros patriarcais, o rebolado das negras ocidentais, o vocabulário, o ritmo do andar, o jogo de capoeira, os ranchos, o euforismo lúdico, a devoção a Sāo Miguel, oxossl dos jêje-nagôs, padroeiro dos capoeiras angolanos e padrinho da fortaleza em Luanda.

Foi necessário que um escritor português viesse ao Brasil, em uma das suas múltiplas viagens, um escritor com os olhos sempre maravilhados perante o fascínio tropical e que ele se transformasse num carloca, baiano, mineiro, cearense, para escrever ao jeltinho brasilelro - ou melhor luso-afro-brasileiro - os poemas, cantigas, xácaras do Violăo de Morro, ( ${ }^{82}$ ) do qual, para concluir, transcrevemos estes versos, tributo de Vitorino Nemésio à honra que the conferimos de cidadão luso-afro-brasllelro:

"Foi em Água de Mininos,

Na Bahla, flor do mar.

Oue o portugués percebeu

Que isto de ser brasllelro

E questão de começar".

(01) Pretácio Bênçāo Paterna an "Sonhos d'Ouro", phrinas 691/702, de José de Alencar. Obra Completa, vol. I - Romanoe Urbano, Rio de Janeiro, Editora José Aguiler Ltda., 1959. 
(02) A críticn de Pinheiro Chasas a José de Alenear está transcrita em Alencar a "Lingua Brasiteira" it Gladstone Chases de Melo, publicado pelo Conselho Federal de Cultura. Vale a pena citar o que seăue: "Näo: esse nāo é o defeito que me parece dever notar-se na Iracema: o defeito que eu vejo nessa lenda, o defeito que en vejo em todos os livros brasileiros, e contra o qual näo cessarei de bradar intrepidamente, í a falta de correção na lingungem portuguesa, ou antes a mania de tornar o brnsileiro uma lingun diferente do velho portugués, por meio de neologismos nrrojados e injustificávcis. e de insubordinaçōes gramaticais, que (tenham cauteIn 1) chegaräo a ser risfveis se quiserem tomar as proporçōes duma insurreiçāo cm regra contra a tirania de Lobato".

(03) Ver o artigo de Josué Montello, "Presença de Portugal no Maranhäo", na Revista Luso-Brasileirn Atlantico, nova série, n.* 1, SNI - AN, Lisban - Rio de Janeiro, 1946. páginas 15 a 24.

(04) Reeensīo crítica de Alvaro Ling ì Biografia de Gonçalres Dias, de Lícia Mixuel Pereira, na Revista Luso-Brasileira Atlintico. n. ${ }^{\circ}$ 5, SNI - DIP. Lisboa - Rio de Janeíro, 1044, pákinas 183 a 185.

(06) Ver 'Questäo Filológica (Incompleto - 1874)" em José de Alenear, Obra Completa". vol. IV. Teatro, Poesia, Crünica, Ensaios Literärios, Escritos Polf́ticos e Epistolário. Companhia Editora José Axuilar Ltda.. 1960, páginas 939 a 961.

(06) Melo. Gladstone Chaves de - Alenear e a Linga Brasileira. 3,* edição, ConselheiFeckral de Cultura, Rio de Janeiro, 1972, paginas 35/36.

(07) "O Nosso Cancioneiro - Cartas no Sr. J. Serra. Ensaios Literários". em Obra Completa de Jasé de Niencar, ediçōo jú citada, páginas 961 a 983.

(08) Cunha. Celso - Línga Portuguesa e Realidade Brasilefra. Colesāo Temas de Todo - Tempo - 13. Editora Tempo Brasileiro. Rio de Janeiro, 1968, páginas 39/40.

(09) Ver o Pús-Escrito da 2." edição de Iracema. Para este trabalho consultamos a edigăo do Centenńrio, publicada em 1965 nela Imprensa Universitária do Cenrá, precechida de notivel introdução do crítico Braga Montenezro.

(10) Prefício a Lírica de Joño Minimo, em Obras de Almeida Garrett, vol. I. Lello \& Irmāos Editores, Porto. 1963. púxina 1497.

(11) Ollvelra, José Osório de - "A Literatura Brasileira em Portugal". Atlintico. Revista Luso-Brasileira. SNI - DIP. Lisboa - Rio de Janeiro, 1944, n. ${ }^{\circ}$. pácinas 191 a 194 .

(12) Ver correspondéncia de Fradique Mendes em Obra Completa de Eça de Queirós, vol. 1. Companhia Editorn Jose Aguilar. Rio de Japeiro, 1970. päginas 164/165.

(13) Ver Obras Completas de Almeida Garrett, ediçāo já citacha.

(14) Ver Obra Completa de Eça de Queirós, ediçāo já cilads.

(15) E fundamental, para a compreensāo da obra de Garrett, a leitura do ensaio de Auguato da Costa Dias, "Estilística e Dialética" que precede a edicino das Vingens as Minha Terra, preparada por aquele critico para a coleçäo Obras Literárias de Almeida Garrett, publicada pela Portugílie Editora, de Lisbos.

(16) Ver Paiva Monteiro. Ofélia Milheiro Caldas - A Formaģ̌o de Almelda Garrett. Experiêneia - Criaçĩo. Centro de Estudos Românticos. Faculdade de Letras da Univer- 
sidade de Caimbra, vol. 1. Coimbra, 1971, página 107.

(17) Ver a comunicaçūo ajresentada por Silvio Elia no $\mathrm{V}$ Colóquio Internacional de Estudos Luso-Brasileiros: "A Difusĩo das Linguas Europélas e a Formaçīo das Variedades Ultramarinas, em Particular dos Crioulos (Aplicaçüo Especial no Portuguès do Brasil)", em Actas, vol. IIJ. Coimbru, 1966, pásinas 217 a 254.

(18) Celso Cunba transcreve a carta de Mário de Andrade em Lingua Portuguesa e Realidade Brastleira.

(19) Coutinho, Afrâtnlo - Introdação i Literatura no Brasil, Editora Distribuidora de Livros Escolares Ltrik.. T.: Ed, llio de Janeiro, 1972, pisina 234.

(20) Ob. cit., página 289.

(21) Ver citação de Celso Cunha em Lingua Portuguesa c Rcalidade Brasileira.

(22) Mendonçu, Fernundo - O Romance Nordestino e o Romunce Neo-Realista in Trê: Ensaios de Literatura. Faculdade de Filosoria, Ciencins e Letras de Assis. São PauJo, 1967, páginas 27 a 41.

(23) Saraivn, Arnalda - A Língua Portuguesa e o Modernismo Brasileiro 10 Exemplo de Carlos Drummond de Andrade) In Arquivos do Centro Cultural Portugués, vol. II. Fundação Calouste Gulbenkían. Paris, 1970, páginas 623 a 631.

(24) Crenos ter sido este o primeiro trabalho sobre a linguagem do angolano Luandino Vicira. Convem lڤ-lo. Linguagem e Criaçño insere outros textos críticos sobre problemas lingústicos e literários. O livro taz parte da coleç̄o Cadernos Peninsulares, novn série, Ensuio 2. Assirio \& Alvim, Lisbon, 1973, páginas 85 a 93.

(25) Azevedo Filho, Leudegário Amarante de - Contribuiçāo du Literatura Brnsileira para a Lingua Portuguesa in Revista de Portagal, Lingua Portuguesa, série "A", vol. XXXIV (275). Mnio, 1969.

(26) Ver n comunicuçüo de Manuel Snraibn Barreto "O Ensino do Portuguès como Lingua Seguncia en Africa'. no I Simpósto Luso-Brasitciro sobre a Linsua Portuguesu Contemporāneu, eni Actos. Coimbra, 1968, púxinus 140 a 147.

(27) Silveira, Luis - O Portugués no Brasil c as Lingung Africanas in Atlântico, Revista Luso-Brusileira, nova série, n. ${ }^{\circ} 3$, SNi - AN. Lisboa - Rio de Janeiro, 1947. páginas 92 a 94.

(28) Ver Celso Cunha, ob. cit.

(29) Estudo publicado pela Agència Geral do Ultramar. Lisboa. 0 aulor investigou em profundidade us relaçōes polfticas, comerciais, cconômiens, culturais e cientfficas entre Angola e o Brasil, no nerfodo de 1808 a 1830. Lisboa, 1968.

(30) Ver o nrefácio de Giuseppe Mea à antologia Poexin Angolana de Revolta. Paisagem Editora. Porto, 1975.

(31) Ver antologia de Cámara Cascudo publicada pela José Ollmplo Editora, que inclui trechos do livro Made in Africa.

(32) Nemésio, Vitorino - Violāo de Morro. Tem xúcara, tem samba, tem Farsa Drumática de 2 nezros do Cais Maui infilizes no Bicho, tem Balada da rua do Catete e de Inferninho de Copacabana $\&$ sexuidas de 9 rotnances da Bahin narrando fielmente os viridicos e espantosos sucessos do luzre FLOR d'ANGRA, da praca do mesmo nome, na IJha Terceira, pritrin do Autor, com 20 marsanos do Pará. $E$ a dança de Xangô com Dazinha, láí do Pégi de Anfsia, iahorixã māe de Santo no grande candomblé de Matatu Pequeno. Bem como os Romances do imigrante de barea FLOR DAS MARES que vai numa buate chic e vira penitente do Desterro \&. Lisbon MCMLXVIII. Na Impressão das Ediçūes Panoramn, em São Pedro d'Alcântara, à Taipas. 